\title{
LANGKAH LANGKAH DALAM MERUMUSKAN RENCANA TERKAIT DENGAN SESUAINYA TINDAKAN KEPERAWATAN BERDASARKAN SOP
}

\author{
Agnes Jessica Lubis
}

Jessikaagnes8@gmail.com

\section{Latar belakang}

Semua pekerjaan baik dalam profesi maupun yang lain selalu dituntut untuk melakukan hal yang sangat baik dan menguntungkan, baik untuk menguntungkan si pekerja atau siklien. Salah satu contohnya ialah profesi dibagian tenaga kesehatan, dimana tenaga kesehatan dituntut untuk menjadi sempurna bila memberikan asuhan asuhan seperti asuhan keperawatan. Dimana memiliki tujuan untuk mempercepat kesembuhan siklien ataupun pasien tersebut.

Perencanaan yang menjadi bagian dari manajemen merupakan suatu proses penyusunan yang sistematis mengenai kegiatan-kegiatan yang perlu dilakukan untuk mengatasi masalah-masalah yang dihadapi dalam rangka pencapaian tujuan yang telah ditetapkan. Perencanaan dapat pula diartikan sebagai cara bagaimana mencapai tujuan dengan sumber daya yang ada supaya lebih efisien dengan memperhatikan lingkungan sosial budaya, fisik dan biologik (Litbangkes Depkes RI, 2002)

PERENCANAAN kesehatan merupakan suatu ketelitian, suatu interpretasi yang cermat serta suatu upaya pengembangan pelayanan kesehatan yang dapat diatur dengan dilaksanakannya, atas dasar pemanfaatan seluruh ilmu pengetahuan modern serta pengalaman yang dimiliki, 2 sedemikian rupa sehingga terpenuhi kebutuhan kesehatan masyarakat berdasarkan sumbersumber yang tersedia. Perencanaan kesehatan merupakan suatu proses yang terdiri dari langkah langkah yang berkesinambungan (SEQUENTIAL); artinya suatu langkah tidak dapat dilakukan sebelum langkah sebelumnya terlaksana, menurut WHO.

Sedangkan menurut Menurut Leavy dan Loomba, PERENCANAAN merupakan suatu proses penganalisaan dan pemahaman tentang suatu sistem, perumusan tujuan umum dan tujuan khusus, perkiraan segala kemampuan yang dimiliki, penguraian segala kemungkinan rencana kerja yang dapat dilakukan untuk mencapai tujuan umum serta khusus tersebut, menganalisa efektifitas dari berbagai alternatif rencana dan memilih satu diantaranya yang dipandang baik serta menyusun rencana kegiatan dari rencana yang terpilih secara lengkap agar dapat dilaksanakan dan 
mengikutinya dalam suatu sistempengawasan yang terus menerus sehingga tercapai hubungan yang optimal antara rencana tersebut dengan sistem yang ada. Perencanaan Kesehatan adalah perencanaan yang ditetapkan pada program kesehatan

Perencanaan kesehatan merupakan suatu proses untuk merumuskan masalah-masalah kesehatan yang berkembang di masyarakat, menentukan kebutuhan dan sumber daya yang tersedia, menetapkan tujuan program yang paling pokok dan menyusun langkahlangkah praktis untuk mencapai tujuan yang telah ditetapkan (Muninjaya, 2004).

Keberhasilan program salah satunya dapat ditentukan oleh perencanaan yang baik, namun masih ada permasalahan yang dihadapi dalam penyusunan perencanaan kesehatan ini. Bakri (2001) menyatakan bahwa permasalahan yang dihadapi dalam perencanaan kesehatan adalah belum adanya Tim Khusus yang dapat mengelola manajemen perencanaan kesehatan kabupaten/kota; masih lemahnya kemampuan petugas kesehatan dalam berbagai aspek proses perencanaan; masih kurang dilibatkannya masyarakat dan sektor terkait dalam proses perencanaan kesehatan dan belum digunakannya model/siklus perencanaan tertentu dalam proses perencanaan.

\section{Metode}

Metode ini digunakan secara fakta dengan merujuk pada referensi referensi yang dapat dipercaya seperti contohnya ialah jurnal jurnal, e-book, serta buku teks . Dengan menggabungkan dari referensi referensi yang faktual, maka penulis berharap artikel ini dapat membantu orang orang yang membutuhkan informasi tentang langkah langkah yang terkaitnya perencanaan dalam tindakan kesehatan.

\section{Hasil}

Dalam penyusunan perencanaan di Dinas Kesehatan Kabupaten Padang Pariaman ditemukan tenaga perencana belum memakai alur perencanan yang sama akan tetapi dalam menetapkan program/kegiatan semua sudah berdasarkan pada prioritas masalah. Langkah-langkah perencanaan yang digunakan oleh masing-masing tenaga perencana atau masing-masing seksi masih berdasarkan pengetahuan dan mengadopsi dari cara-cara penentuan prioritas dari bidang masing-masing. Ada yang memulai perencaaan dari meriview renstra serta melakukan analisis 
masalah berdasarkan masalah yang berdampak kepada peningkatan angka kematian maka itu yang dijadikan prioritas dalam perencanaan

nantinya, ada juga dengan melihat target program yang tak tercapai tahun lalu direncanakan lagi serta ada juga dengan memulai dari menganalisa data sepuluh penyakit terbanyak. Hal ini disebabkan karena belum ada panduan ataupun pedoman yang jadi acuan tiap seksi dalam menyusun perencanaan

Untuk perencanaan tahunan, alur perencanaan dimulai dari review renstra SKPD, analisis kondisi dan masalah sektor SKPD, perumusan tujuan dan sasaran tahun rencana, perumusan program dan kegiatan SKPD tahun rencana dan dalam perumusan program dan kegiatan perlu memperhatikan standar pelayanan minimal, serta identifikasi program kegiatan pusat dan propinsi, sampai nantinya disusun rancangan akhir renja SKPD (LGSP, 2007).

Dalam menyusun perencanaan kesehatan perlu memperhatikan alur proses penyusunannya dan setiap tenaga perencana diberikan panduan penyusunan rencana, sehingga nantinya dapat dihasilkan sebuah perencanaan yang bermutu dan sesuai dengan aturan yang ada. Selain memperhatikan alur perencanaan yang terpadu, maka konsultasi sangat diperlukan juga bagi kelancaran proses perencanaan terutama konsultasi ke pimpinan dan juga ke Pemerintah Daerah yang diwakili oleh Bappeda. Konsultasi berguna dalam memahami maupun memperjelas program/kegiatan yang diusulkan.

Di Dinas Kesehatan Kabupaten Padang Pariaman ditemukan bahwa pelaksanaan konsultasi sehubungan dengan perencanaan dilakukan ke Bappeda yang diwakili oleh Kepala Dinas, Sekretaris Dinas maupun Sub Bagian Perencanaan. Hal yang dikonsultasikan lebih kepada berapa anggaran dana yang dialokasikan untuk semua kegiatan yang diusulkan. Dalam konsultasi, kemampuan melobi dari tenaga perencana yang datang ke Bappeda sangat menentukan besaran anggaran dana yang akan dialokasikan untuk seluruh kegiatan.

Apabila bisa meyakinkan pihak Bappeda akan pentingnya kegiatan tersebut dilakukan maka kemugkinan kegiatan yang diusulkan tidak akan dihapus dari usulan rencana. Untuk menyinkronkan program dan kegiatan dengan propinsi agar nantinya bisa memanfaatkan dana dekonsentrasi propinsi biasanya konsultasi langsung dilakukan oleh para pemegang program, sehingga dalam menyusun perencanaan nantinya para pemegang program sudah mengetahui 
program dan kegiatan yang didanai propinsi dan tidak menganggarkan lagi program dan kegiatan tersebut dalam anggaran APBD. Tetapi dalam pelaksanaannya, monitoring terhadap pelaksanaan konsultasi masih kurang maksimal, sehingga berakibat pada kurang terakomodirnya usulan rencana dari propinsi dalam Renja Dinas Kesehatan Kabupaten Padang Pariaman.

\section{Pembahasan}

Perencanaan adalah tahapan yang penting dalam proses keperawatan, karena menentukan tindakan apa yang akan dilakukan pada tahap pelaksanaan oleh perawat. Penyusunan perencanaan keperawatan keluarga hendaknya dilaksanakan bersama klien dan keluarga. Perawat dan keluarga secara bersama-sama akan mampu mengidentifikasi sumber yang dimiliki oleh keluarga yang dapat dimanfaatkan dalam menyelesaikan masalah kesehatan yang terjadi. Perencanaan keperawatan mencakup tujuan umum dan khusus yang didasarkan pada masalah yang dilengkapi dengan kriteria dan standar yang mengcau pada penyebab. Selanjutnya merumuskan tindakan keperawatan yang berorientasi pada kriteria dan standar.

Rencana asuhan keperawatan adalah suatu proses informasi, penerimaan, pengiriman, dan evaluasi pusat rencana yang dilakukan oleh seorang perawat profesional. Format rencana asuhan keperawatan membantu perawat untuk memproses data yang diperoleh selama tahap pangkajian dan penegakan diagnosis keperawatan. Rencana asuhan keperawatan ditulis dalam suatu bentuk yang bervariasi guna mempromosikan perawatan yang meliputi perawatan individu, perawatan

yang berkelanjutan, sebagai media komunikasi, dan evaluasi keberhasipan asuhan keperawatan.

Rencana intervensi keperawatan adalah desain spesifik dari intervensi yang disusun untuk membantu klien dan mencapai kriteria hasil. Rencana intervensi tersebut disusun berdasarkan komponen penyebab dari diagnosis keperawatan. Oleh karena itu rencana intervensi harus mengdefinisikan suatu aktivitas yang diperlukan untuk membatasi faktor-faktor penunjang suatu masalah.

Perbedaan rencana intervensi keperawatan dan tindakan medis. Rencana intervensi keperawatan adalah rencana yang disusun perawat untuk kepentingan asuhan keperawatan yang akan digunakan oleh perawat yang menyusun maupun perawat lainnya. Sedangkan rencana intervensi sebagai suatu tugas yang didelegasikan adalah rencana yang disusun oleh dokter dokter untuk 
dilaksanakan oleh staf perawat. Instruksi dokter bukanlah instruksi untuk perawat melainkan ditujukan untuk klien tetapi intervensinya dilaksanakan oleh perawat. Kedua intervensi tersebut memerlukan suatu pengembilan keputusan yang independen, karena secara hukum perawat harus menentukan apakah memang sudah sesuai untuk melaksanakan suatu intervensi berdasarkan standar praktik. Sedangkan rencana tindakan medis difokuskan pada kegiatan yang berhubungan dengan diagnostik dan pengobatan (medikasi) berdasarkan kondisi klien. Tindakan tersebut didelegasikan kepada perawat dan profesi kesehatan lainnya. Rencana asuhan keperawatan ditujukan pada kegiatan yang berhubungan dengan promosi dan mempertahankan atau menjaga kesehatan klien. Rencana intervensi tersebut dapat dikategorikan menjadi dependen, interdependen, dan independen.

Karakteristik Rencana Asuhan Keperawatan

1. Konsisten dengan rencana intervensi keperawatan.

2. Berdasarkan prinsip-prinsip ilmiah (rasional).

3. Berdasarkan kondisi klien (individu).

4. Digunakan untuk menciptakan suatu situasi yang aman dan terapeutik

5. Menciptakan suatu situasi pengajaran.

6. Menggunakan sarana yang sesuai.

Pengembangan/Penyusunan Rencana Asuhan Keperawatan Perawat menggunakan metode ilmiah dalam penyusunan rencana asuhan keperawatan yang meliputi mendefinisikan masalah (diagnosis), mengidentifikasi adanya kemungkinan alternatif, dan menyeleksi alternatif yang mungkin. Jika diagnosis keperawatan dan kriteria hasil suda tersusun, maka perlu diambil keputusan tentang bagaimana mempromosikan, mempertahankan, atau meningkatkan kesehatan klien.

Berdasarkan hasil pencarian yang didapat menyatakan bahwa langkah-langkah perencanaan dalam proses keperawatan diantaranya yaitu prioritas masalah, kriteria hasil, rencana intervensi dan pendokumentasian. Komponen-komponen tersebut sangat membantu pada proses evaluasi keberhasilan asuhan keperawatan yang telah diimplementasikan. 
Menurut PPNI, 2010 pelayanan kesehatan yang berkualitas perlu ditunjang dengan pelayanan keperawatan yang berkualitas, karena pelayanan keperawatan merupakan intergal dari pelayanan kesehatan. Perawat sebagai tenaga kesehatan yang memberikan pelayanan asuhan keperawatan 24 jam pada pasien, perawat melakukan tindakan keperawaan yang banyak dan yang dapat menimbulkan resiko kesalahan yang begitu besar. Keberagaman pelayanan tersebut apabila tidak dikelolah dengan baik akan berdampak pada mutu pelayanan keperawatan yang diberikan (Oktafia, 2015).

Overan merupakan teknik atau cara untuk menyampaikan dan menerima sesuatu (laporan) yang berkaitan dengan keadaan pasien. Overan pasien harus dilakukan seefektif mungkin dengan menjelaskan secara singkat, jelas dan lengkap tindakan mandiri perawat, tindakan kolaborasi yang sudah dan yang belum dilakukan serta perkembangan pasien saat itu, informasi yang disampaikan harus akurat sehingga kesinambungan asuhan keperawatan dapat berjalan dengan sempurna. (Nursalam, 2011).

Menurut penelitian Quiteria Manopo, 2013 melakukan penelitian pada perawat pelaksana di RSUD GMIM kalooran Amurang, hasilnya tersebut menunjukkan bahwa kategori kurang baik didapatkan ada 22 orang atau 36,7\% dan 38 orang atau 63,3\% kategori baik dalam melakukan timbang terima pasien sesuai dengan SOP, penerapan timbang terima pasien sesuai dengan SOP masih banyak yang belum melakukan, sehingga keselamatan pasien harus lebih ditingkatkan lagi.

Berdasarkan data yang diperoleh dari RSUD Achmad Mochtar Bukittinggi, dan perawat ruang rawat inap terdapat 101 orang perawat pada bulan Januari - Desember 2016 dari 9 ruangan yaitu ruang Paru, ruang THT, ruang Mata, ruang Neurologi, ruang Interne wanita, ruang Interne pria, ruang Bedah, ruang Anak, ruang Jantung. Pelaksanaan timbang terima ini seringkali masih menjadi permasalahan di setiap rumah sakit. Hasil penelitian Mayasari (2011) di Ruang Kelas I Irna Non Bedah (Penyakit Dalam) RSUP DR. M. Djami Padang ditemukan pada pelaksanaan timbang terima (overan) yang diobservasi pada pergantian shift pagi - sore - malam yang dilaksanakan tiga kali pertemuan tidak ada yang dilaksanakan dengan efektif dengan rata - rata persentase yang diperoleh adalah $60.3 \%$. 
hasil penelitian Hardianti Anthon (2012) tentang penerapan metode tim (MPKP), masih ada $25,6 \%$ perawat yang belum melaksanakan sepenuhnya timbang terima diruang rawat inap di RSUD Kabupaten Majene. Berdasarkan survey awal yang telah dilakukan pada tanggal pada masingmasing perawat di ruang rawat inap bedah dan ruang rawat inap intern wanita dan pria RSUD Achmad Mochtar Bukittinggi terhadap orang perawat didapatkan ada 7 orang perawat yang masih mempunyai pengetahuan yang masih kurang paham terhadap pelaksanaan timbang terima sesuai SOP.

Menurut WHO, 2007 Keselamatan pasien telah menjadi isu dunia yang perlu mendapat perhatian bagi sistem pelayanan kesehatan. Keselamatan pasien merupakan prinsip dasar dari pelayanan kesehatan yang memandang bahwa keselamatan merupakan hak bagi setiap pasien dalam menerima pelayanan kesehatan. World Health Organization (WHO) Collaborating Center for Patient Safety Solutions (JCI) pada tahun 2005 telah memasukan masalah keselamatan pasien dengan menerbitkan enam program keselamatan pasien dan sembilan panduan atau solusi keselamatan pasien dirumah sakit pada tahun 2007 (Manopo dkk, 2013).

Berdasarkan analisa peneliti bahwa setengah dari perawat diruang rawat inap di RSUD Dr. Achmad Mochtar Kota Bukit tinggi mempunyai pengetahuan yang baik dalam pelaksanaan timbang terima dan separoh lagi memiliki pengetahuan yang rendah dalam pelaksanaan timbang terima sesuai SOP. dan dari teori Notoatmodjo menyimpulkan bahwa dari pengalaman perawat bekerja akan berpengaruh terhadap pelaksanaan timbang terima yang dilaksanakan perawat.

Hal ini terkait dengan hasil penelitian diketahui bahwa perawat mengatakan timbang terima dilaksanakan 3x dalam 24 jam disetiap ruangan, perawat juga mengatakan pelaksanaan timbang terima dilakukan setiap pergantian shif dan perawat primer dan keduan anggota shift dinas bersama-sama secara langsuang melihat keadaan pasien dan interaksi yang dilakukan pada pasien dilakukan setiap saat timbang terima, sebagian perawat mengatakan timbang terima dilakukan tidak selalu dipimpin oleh karu terkadang timbang teria dipimpin oleh katim, waktu yang digunakan untuk mengunjungi pasien lebih dari 5 menit juga mampu melaksanakan timbang terima pasien sesuai SOP dengan baik. 
Seberapa lama perawat bekerja maka akan semakin menambah pengalaman dan wawasan perawat yang akan mempengaruhi tindakan yang akan dilakukan perawat. Untuk itu peneliti setuju dengan teori Notoatmodjo. Pada dasarnya lama kerja juga dapat berpengaruh terhadap pelaksanaan timbang terima perawat karena semakin lama kerja perawat maka semakin baik pelaksanaan timbang terima yang dilakukan, hal ini disebabkan dari pengalaman perawat yang sudah didapat selama bekerja. Baik atau tidaknya pelaksanaan timbang terima perawat akan menentukan seberapa jauh perawat memahami pentingnya timbang terima dilakukan.

Ada hubungan terhadap pengetahuan perawat dengan pelaksanaan timbang terima pasien sesuai SOP. Disarankan, rumah sakit untuk terus meningkatkan pengetahuan SDM keperawatan serta melakukan supervisi pelaksanaan timbang terima pasien sesuai SOP.

\section{Penutup}

a.kesimpulan

Ada hubungan terhadap pengetahuan perawat dengan pelaksanaan timbang terima pasien sesuai SOP. Jika seorang perawat memiliki pengetahuan tentang tindakan yang dilakukan sesuai dengan SOP maka perencanaan perencanaan yang akan dilaksanakan sesuai dengan keperawatan dipertimbangkan akan membaik.

b. saran

Disarankan, rumah sakit untuk terus meningkatkan pengetahuan SDM keperawatan serta melakukan supervisi pelaksanaan timbang terima pasien sesuai SOP.

\section{Daftar pustaka}

- Jasrida Yunita,2012 Proses Perencanaan Tahunan Dinas Kesehatan Kabupaten Padang Pariaman Jurnal Kesehatan Komunitas, Vol. 1, No. 4, Mei 2012

- Dermawan, D. (2012). Proses Keperawatan Penerapan Konsep \& Kerangka Kerja (1st ed.). Yogyakarta: Gosyen Publishing.

- Kodim, Yulianingsih. (2015). Konsep DasarKeperawatan. Jakarta: TIM. 
- REAL in Nursing Journal (RNJ), Vol. 1, No. 2 Febrina, W; Yenni \& Ramadhani, S (2018). RNJ. 1(2) : 60-66

- Febrina, W. (2018). PENGETAHUAN PERAWAT TERHADAP PELAKSANAAN TIMBANG TERIMA PASIEN SESUAI SOP. Real in Nursing Journal, 1(2), 60-66

- Hrp, E. R. (2019). MELAKSANAKAN SASARAN KESELAMATAN PASIEN DENGAN BENAR DI RUMAH SAKIT. Osf.io

- Pagala, I., Shaluhiyah, Z., \& Widjasena, B. (2017). Perilaku Kepatuhan Perawat Melaksanakan SOP Terhadap Kejadian Keselamatan Pasien di Rumah Sakit X Kendari. Jurnal Promosi Kesehatan Indonesia, 12(1), 138-149

- Nurhaliza, S. (2019). Peran Perawat Dalam Menerapkan Keselamatan Pasien Di Rumah Sakit. Osf.io

- Nursalam. (2012). Manajemen Keperawatan Aplikasi dalam Praktik Keperawatan Profesional.Edisi 3. Jakarta: Salemba Medika

- Yanti, R. I., \& Warsito, B. E. (2013). Hubungan karakteristik perawat, motivasi, dan supervisi dengan kualitas dokumentasi proses asuhan keperawatan. Jurnal Manajemen Keperawatan, 1(2)

- Simamora, R. H. (2005). Hubungan Persepsi Perawat Pelaksana Terhadap Penerapan Fungsi Pengorganisasian Yang Dilakukan Oleh Kepala Ruangan Dengan Kinerjanya Diruang Rawat Inap RSUD Koja Jakarta Utara (Doctoral dissertation, Tesis FIK UI, Tidak dipublikasikan).

- Butar-Butar, J., \& Simamora, R. H. (2016). Hubungan Mutu Pelayanan Keperawatan dengan Tingkat Kepuasan Pasien Rawat Inap di RSUD Pandan Kabupaten Tapanuli Tengah. Jurnal Ners Indonesia, 6(1), 50-63. 